\title{
Analyzing energy flexibility by demand response in a Finnish district heated apartment building
}

\author{
Yuchen $\mathrm{Ju}^{1,2^{*}}$, Juha Jokisalo ${ }^{1,2}$, Risto Kosonen ${ }^{1,2,3}$, Ville Kauppi ${ }^{1}$, and Philipp Janßen ${ }^{4}$ \\ ${ }^{1}$ Aalto University, Department of Mechanical Engineering, Espoo, Finland \\ ${ }^{2}$ TalTech, Smart City Center of Excellence, Tallinn, Estonia \\ ${ }^{3}$ Nanjing Tech University, College of Urban Construction, Nanjing, China \\ ${ }^{4}$ Hamburg University of Applied Sciences, Department Environmental Engineering, Hamburg, German
}

\begin{abstract}
In order to realize the vision of climate neutrality, the proportion of renewable sources is increasing in the energy system. To accommodate the energy system, demand response (DR) has been established to make the building energy use flexible. This study aims to investigate the effect of DR actions on energy flexibility in a Finnish district heated apartment building. The rule-based control algorithm was applied for the DR control of space heating based on the Finnish dynamic hourly district heat price. This research was implemented with the validated dynamic building simulation tool IDA ICE. The obtained results show that price fluctuation impacts the DR control and further affects the amount of charging and discharging energies. February has the maximum hourly district heat price with the largest variation, which results in the maximum charging energy of $968 \mathrm{kWh}$ during a single charging period being close to the heat storage capacity of a fully mixed $28 \mathrm{~m}^{3}$ water tank with $\Delta \mathrm{T}$ of $30 \mathrm{~K}$. The studied demand response control can significantly shape the heating power demand of the buildings and increase the flexibility of the energy use.
\end{abstract}

\section{Introduction}

The European Commission aims to achieve the key target for cutting $40 \%$ of greenhouse gas emissions from 1990 levels, increasing the share of renewable energy by $32 \%$, and improving at least $32.5 \%$ of energy efficiency by 2030 [1]. Moreover, the European Commission has set a vision to be climate neutrality by 2050 [2]. Finland has also set an ambitious climate target for reducing greenhouse gas emissions at least $55 \%$ by 2030 compared to the 1990 level [3]. In 2016, district heating (DH) totaled $33 \%$ of energy consumption in Finland [4]. In addition, power and heat generation accounted for $40 \%$ of the total $\mathrm{CO}_{2}$ emissions [4]. This depicts that $\mathrm{DH}$ is prevalent in Finland, offering immense potential for realizing the target.

Increasing the share of renewable energy reduces the use of fossil fuels effectively, thereby reducing $\mathrm{CO}_{2}$ emissions. However, energy generated by renewable sources such as wind and solar power is intrinsically variable. The energy system will become unstable when the proportion of renewable sources increases [5]. Therefore, to accommodate this flexible energy system, thermal energy storage (TES) was introduced both in electricity and DH networks. The integration of TES into the DH network balances the heat supply and demand effectively, thereby decreasing the need for peak generation [6]. In addition, energy consumption needs to be flexible. For this purpose, an active method called demand response (DR) has been introduced.
Dynamic energy price is applied as one of the incentives for prosumers [7] to store or share energy actively. What is more, demand side management techniques have been put forth to optimize production or reduce costs [8]. Therefore, energy flexibility definition is applied for analyzing flexible building demand. There are three characteristics pertinent to the definition: cost saving potential, temporal flexibility, and the amplitude of energy on building level analysis [9].

The cost saving potential of DR has typically been examined based on dynamic electricity prices [10]-[11]. Temporal flexibility and the amplitude of energy modulation were defined mainly to quantify the flexibility potential of TES. Researchers investigated the impacts of thermal mass capacity on the energy flexibility of heated buildings or communities. Three quantification factors were proposed as available storage capacity, storage efficiency, and power-shifting capability, to quantify the active DR characteristics for the structural TES capacity for residential buildings [12]. In addition, two types of flexibility indexes have been defined which combined dynamic energy price and the amount of shifted energy to quantify the ability in residential buildings to minimize the heating energy usage when the price was high and maximize it when the price was low [13]-[14].

The research on flexibility factors is comprehensive addressing cost, time of energy usage, and energy. Although most studies are based on electricity price or electricity consumption, these factors

\footnotetext{
* Corresponding author: yuchen.ju@aalto.fi
} 
can also apply to district heated buildings. However, the research cited above mostly analyzed the flexibility of a single building type. Residential buildings were the most popular. What is more, most of the previous papers investigated the flexibility of buildings with DR control based on dynamic electricity prices. Research is equally limited to the impact of dynamic $\mathrm{DH}$ prices on flexibility. Therefore, analysis of the flexibility of district heated buildings is required with dynamic $\mathrm{DH}$ prices.

This paper investigates ways in which DR affects the energy flexibility of a Finnish district heated apartment building from the perspective of $\mathrm{DH}$ producers. Economic benefits for prosumers have been analysed in Janne's research [15]. The apartment building was simulated and analyzed with the dynamic Finnish DH price.

\section{Methodology}

\subsection{Description of simulation process}

Figure 1 describes the simulation process by a flow chart. Behrang-Sirén method [16]-[17] changed hourly DH price into control signal. Outdoor 24 hour moving average temperature, acceptable indoor air temperature range, and limiting outdoor temperature were employed in the setpoint control algorithm. After that, setpoint smoothing was adopted to minimize the rebound effect and final hourly indoor temperature setpoints were obtained. The apartment building was simulated by IDA ICE 4.8 simulation tool and results were analyzed in Section 5 .

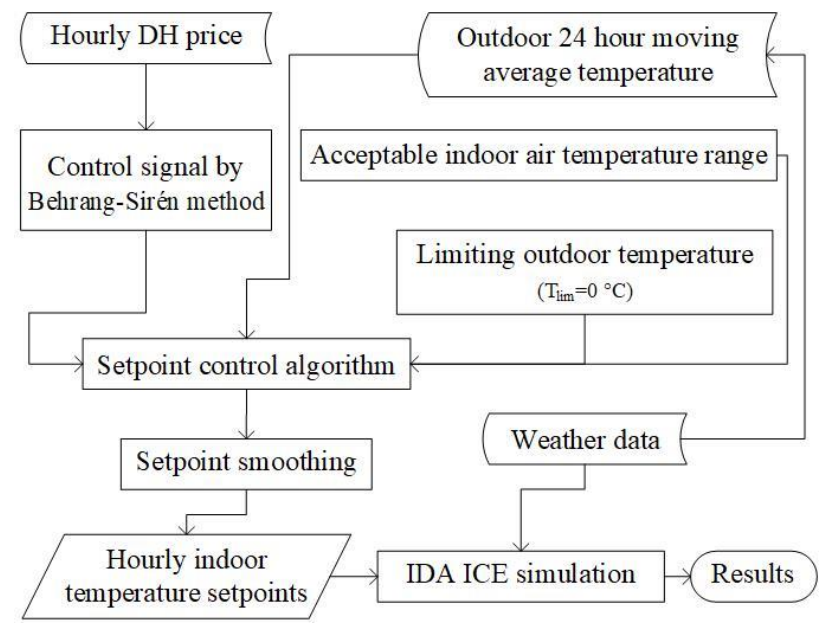

Figure 1. Flow chart of simulation process.

\subsection{Acceptable range of indoor air temperature setpoints}

The acceptable range of indoor air temperature setpoints was defined based on the middle class S2 of the classification of indoor environment by Finnish Society of Indoor Air Quality [18] and the thermal environmental category II of standard EN 15251[19]. According to S2, the operative temperature should keep within $20-23{ }^{\circ} \mathrm{C}$, when the 24-hour moving average outdoor temperature is below $0{ }^{\circ} \mathrm{C}$. The recommended minimum indoor air temperature is $20^{\circ} \mathrm{C}$ in the thermal environmental category II of EN 15251 standard. Based on these, the acceptable indoor air temperature setpoints for space heating were chosen to be from $20^{\circ} \mathrm{C}$ to $23^{\circ} \mathrm{C}$.

\subsection{Hourly DH price}

The Finnish synthetic DH price was adopted which represents a typical district heat producer in Finland and contains both energy and transfer costs and the valueadded tax of $24 \%$ (VAT). In this case, the typical DH system on the production side consists of biomass-fired CHP-plant and oil-fired heat only boiler, which is described more detailed along with the synthetic DH price in Ref. [6].

In this paper, months from January to April and October to December were chosen for analysis because most of the heating demand occurred in these months. The analyzed period is named heating season in this paper. The Finnish synthetic price average, maximum, minimum and standard deviation of each month during the heating season are fluctuated during the coldest winter months. Average values in March and April of the Finnish price are much lower than in other months.

Table 1. Description of the Finnish synthetic DH price.

\begin{tabular}{ccccc}
\hline Month & $\begin{array}{c}\text { Average } \\
(\boldsymbol{\epsilon} / \mathbf{M W h})\end{array}$ & $\begin{array}{c}\text { Maximum } \\
(\boldsymbol{\epsilon} / \mathbf{M W h})\end{array}$ & $\begin{array}{c}\text { Minimum } \\
(\boldsymbol{\epsilon} / \mathbf{M W h})\end{array}$ & $\begin{array}{c}\text { Standard } \\
\text { deviation } \\
(\boldsymbol{\epsilon} / \mathbf{M W h})\end{array}$ \\
\hline Jan. & 67.6 & 138.0 & 32.3 & 26.5 \\
\hline Feb. & 72.1 & 145.4 & 22.4 & 34.5 \\
\hline Mar. & 65.9 & 133.2 & 36.1 & 27.5 \\
\hline Apr. & 44.7 & 54.6 & 28.2 & 5.8 \\
\hline Oct. & 41.3 & 50.0 & 24.1 & 5.3 \\
\hline Nov. & 57.2 & 136.7 & 33.8 & 22.7 \\
\hline Dec. & 65.5 & 136.4 & 27.0 & 30.7 \\
\hline $\begin{array}{l}\text { Heating } \\
\text { season }\end{array}$ & 59.1 & 145.4 & 22.4 & 26.7 \\
\hline
\end{tabular}

\subsection{Weather data}

The simulated apartment building locates in Helsinki in the Finnish climate zone I [20]. Therefore, the heating system was dimensioned by using the design outdoor temperature $-26{ }^{\circ} \mathrm{C}$ with the design indoor air temperature at $21^{\circ} \mathrm{C}$, and simulations were carried out with hourly weather data of Helsinki-Vantaa, test reference year TRY2012 [20]-[21].

Table 2 shows the description of the outdoor temperature of the test reference year. The average temperature of Helsinki during the heating season is -0.3 ${ }^{\circ} \mathrm{C}$. February is the coldest month with the minimum temperature of $-20.6^{\circ} \mathrm{C}$, and the minimum temperatures are quite similar in January, February, and March. 
Table 2. Description of Helsinki test reference year outdoor temperature.

\begin{tabular}{ccccc}
\hline Month & $\begin{array}{c}\text { Average } \\
\left({ }^{\circ} \mathbf{C}\right)\end{array}$ & $\begin{array}{c}\text { Maximum } \\
\left({ }^{\circ} \mathbf{C}\right)\end{array}$ & $\begin{array}{c}\text { Minimum } \\
\left({ }^{\circ} \mathbf{C}\right)\end{array}$ & $\begin{array}{c}\text { Standard } \\
\text { deviation } \\
\left({ }^{\circ} \mathbf{C}\right)\end{array}$ \\
\hline Jan. & -4.0 & 2.8 & -20.4 & 5.7 \\
\hline Feb. & -4.5 & 8 & -20.6 & 7.2 \\
\hline Mar. & -2.6 & 6.2 & -19.9 & 4.6 \\
\hline Apr. & 4.5 & 18.3 & -3.7 & 4.6 \\
\hline Oct. & 6.2 & 13.9 & -2.1 & 3.6 \\
\hline Nov. & 0.5 & 8.9 & -17.8 & 6.3 \\
\hline Dec. & -2.2 & 4.9 & -15 & 4.5 \\
\hline $\begin{array}{c}\text { Heating } \\
\text { season }\end{array}$ & -0.3 & 18.3 & -20.6 & 6.6 \\
\hline
\end{tabular}

\section{Description of the apartment building}

Table 3 lists the properties of the simulated building. The apartment building is connected to the $\mathrm{DH}$ network.

Table 3. Building parameters.

\begin{tabular}{|c|c|c|}
\hline \multicolumn{2}{|c|}{ Parameters } & $\begin{array}{l}\text { Apartment } \\
\text { building }\end{array}$ \\
\hline \multicolumn{2}{|c|}{ Heated net floor area $\left(\mathrm{m}^{2}\right)$} & 4885 \\
\hline \multicolumn{2}{|c|}{ Floor number } & 4 \\
\hline \multicolumn{2}{|c|}{ Envelope area $\left(\mathrm{m}^{2}\right)$} & 4780 \\
\hline \multirow{4}{*}{$\begin{array}{l}\text { U-Value } \\
\left(\mathrm{W} / \mathrm{m}^{2} \mathrm{~K}\right)\end{array}$} & External walls & 0.28 \\
\hline & Roof & 0.22 \\
\hline & Ground slab & 0.36 \\
\hline & Windows & 1.00 \\
\hline \multicolumn{2}{|c|}{ Air leakage rate, $\mathrm{n}_{50}(1 / \mathrm{h})$} & 1.00 \\
\hline \multicolumn{2}{|c|}{ Design power at design temperature $(\mathrm{kW})$} & 169 \\
\hline \multicolumn{2}{|c|}{$\begin{array}{l}\text { Air change rate of mechanical ventilation } \\
(\mathrm{CAV}) \text { without heat recovery }(1 / \mathrm{h})\end{array}$} & 0.5 \\
\hline \multicolumn{2}{|c|}{$\begin{array}{l}\text { Annual internal heat gains of lighting } \\
\left(\mathrm{kWh} / \mathrm{m}^{2} \mathrm{a}\right)\end{array}$} & 15.9 \\
\hline \multicolumn{2}{|c|}{$\begin{array}{l}\text { Annual internal heat gains of equipment } \\
\left(\mathrm{kWh} / \mathrm{m}^{2} \mathrm{a}\right)\end{array}$} & 11.3 \\
\hline \multicolumn{2}{|c|}{$\begin{array}{l}\text { Heating energy demand of domestic hot } \\
\text { water (DHW) }\left(\mathrm{kWh} / \mathrm{m}^{2}\right)\end{array}$} & 35 \\
\hline
\end{tabular}

\section{Rule-based demand response control}

\subsection{Trend of district heat price}

It was assumed that the moving future 24-hour prices of DH were known. Control signals (CS) were calculated by the Behrang-Sirén method $[16,17]$. The price trend is decreasing, increasing, or flat with values $-1,+1$, or 0 respectively. Marginal value that can be chosen freely, hourly energy (DH) price (HEP), and its future average HEP are all together to decide control values. The control signal is formed as shown below.

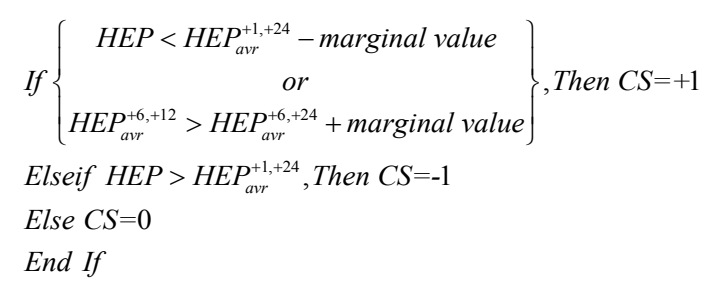

where $H E P^{+1+24}$ avr is the future average HEP from hour 1 to $24, € / \mathrm{MWh} ; \mathrm{HEP}^{+6+12}$ avr is the future average HEP from hours 6 to $12, € / \mathrm{MWh} ; H E P^{+6+24}$ avr is the future average HEP from hours 6 to 24, €/MWh.

If the marginal value is chosen to be small, the HEP will be more often smaller than 24-hour average price subtracted the marginal value or $H E P^{+6+12}$ avr will be more often higher than the summation of $\mathrm{HEP}^{+6+24}$ avr and the marginal value, which means that the control signals get more often value +1 for charging, and the price trend is classified increasing.

A higher marginal value represents the opposite situation and it raises the threshold of the further price trend judged as increasing. For comparison, marginal values of $15 € / \mathrm{MWh}$ and $75 € / \mathrm{MWh}$ were applied in this study based on Martin's research [22].

\subsection{Setpoint control algorithm}

The control algorithm for the apartment build was adopted as shown in Figure 2 [22]. It controls the hourly indoor air temperature by the space heating system.

In Figure $2, T_{S H, \min }, T_{S H, \max }$, and $T_{S H \text {, norm }}$ are the minimum $\left(20^{\circ} \mathrm{C}\right)$, maximum $\left(23^{\circ} \mathrm{C}\right)$, and the normal $(21$ ${ }^{\circ} \mathrm{C}$ ) indoor temperature setpoints. To avoid overheating, limiting outdoor temperature was chosen to be $0{ }^{\circ} \mathrm{C}$ based on Martin's research [22].

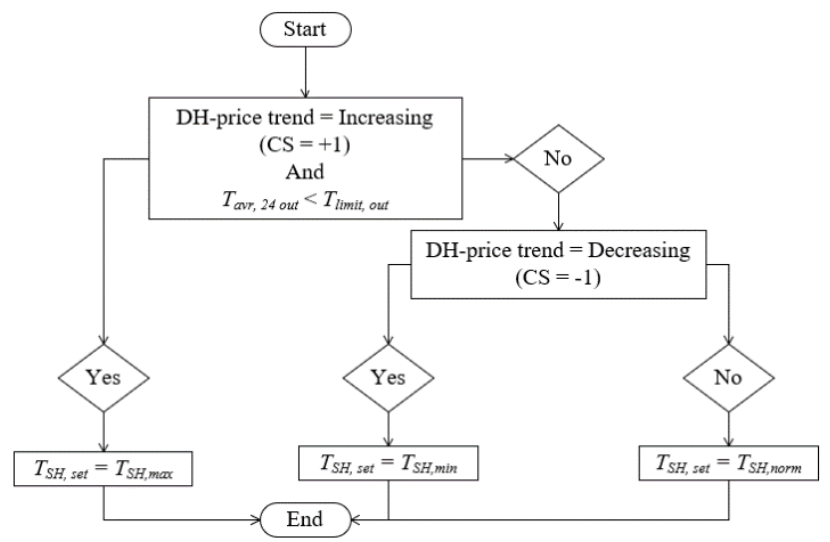

Figure 2. Control algorithm for space heating.

\subsection{Definition of flexibility factors}

Figure 3 presents the calculation principle of flexibility factors. The solid line is the demand curve without DR actions. The dotted line is the curve with DR actions. The red areas represent the moment when the energy price trend is increasing and the indoor temperature setpoint is set to maximum. Energy is stored mainly in the thermal mass of building structures during the charging period. The green areas represent the opposite situation and heating power demand is lower because heat energy charged to the building 
structures releases with the decrease of the indoor air temperature.

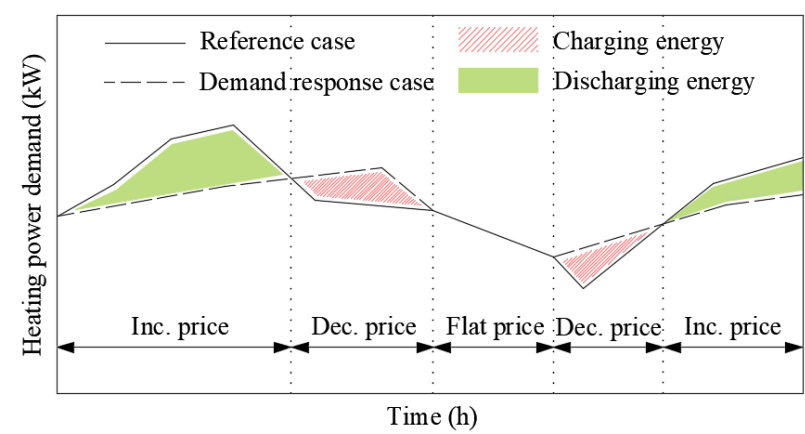

Figure 3. Charging and discharging energies during increasing and decreasing price trends.

Heating power demand represents the total $\mathrm{DH}$ power of the building which includes space heating, ventilation, and DHW. Charging and discharging energies which represent the differences in space heating demand are described as Eqs. (2) and (3).

$$
\begin{gathered}
q_{\text {charging }}=\int_{0}^{\tau_{\text {charging }}}\left(P_{\text {temp,inc. }}-P_{\text {ref }}\right) \cdot d t \\
q_{\text {discharging }}=\int_{0}^{\tau_{\text {discharging }}}\left(P_{\text {temp,dec. }}-P_{r e f}\right) \cdot d t
\end{gathered}
$$

where $q_{\text {charging }}$ is the charged energy of a single charging period compared with a reference case without DR, $\mathrm{kWh}$; q discharging is the discharged energy of a single discharging period, $\mathrm{kWh}$; $\tau_{\text {charging }}$ is the hours of a single charging period, $\mathrm{h}$; $\tau_{\text {discharging }}$ is the hours of a single discharging period, $\mathrm{h} ; P_{\text {temp,inc }}$ is the power demand when the indoor air temperature increases, $\mathrm{kW} ; P_{\text {temp,dec }}$ is the power demand when the indoor air temperature decreases, $\mathrm{kW} ; P_{\text {ref }}$ is the power demand of reference cases without DR, $\mathrm{kW}$.

The seasonal energy flexibility factors are shown in Eqs. (4) and (5).

$$
\begin{gathered}
F F^{+}=\frac{\int_{0}^{\tau_{h s}} p^{+} \cdot d t}{\int_{0}^{\tau_{h s}} p_{r e f} \cdot d t} \\
F F^{-}=\frac{\int_{0}^{\tau_{h s}} P^{-} \cdot d t}{\int_{0}^{\tau_{h s}} p_{r e f} \cdot d t}
\end{gathered}
$$

where $\mathrm{FF}^{+}$is the percentage of charged energy during the heating season compared with a reference case without DR, $\mathrm{kWh} ; \mathrm{FF}^{-}$is the percentage of discharged energy, $\mathrm{kWh} ; \tau_{h s}$ is the total hours of the heating season, $\mathrm{h} ; P^{+}$is the hourly power difference for charging compared with the reference case. $\mathrm{kW} ; P^{-}$is the hourly power difference for discharging compared with the reference case, $\mathrm{kW}$.

\section{Results}

The simulation cases include both a reference case without DR-control and DR-controlled cases. The reference case was simulated with a constant indoor temperature setpoint of $21^{\circ} \mathrm{C}$ allowed to compare the DR controlled cases with variable indoor air temperature setpoints. Table 4 lists the details of different simulation cases.
Table 4. Simulation cases of the Finnish apartment building (FAB).

\begin{tabular}{cc}
\hline Cases & $\begin{array}{c}\text { Marginal value with DR } \\
(€ / \mathrm{MWh})\end{array}$ \\
\hline FAB (Reference) & No DR \\
\hline FAB-DR-15 & 15 \\
\hline FAB-DR-75 & 75 \\
\hline
\end{tabular}

\subsection{Setpoint variations}

Variations of indoor temperature setpoints during the heating season were analyzed based on the algorithm introduced in Section 4.2 with the Finnish synthetic DH price. Figure 4 describes the range of the hours that the algorithm sets the setpoint to $23^{\circ} \mathrm{C}$ or $20^{\circ} \mathrm{C}$ per month during the heating season with marginal value 15 $€ / M W h(D R-15)$.

Whiskers in these box charts show the values for the minimum to maximum. The interquartile range is from $25 \%$ to $75 \%$ of them. For example, in February, the maximum charging hours are 48 which means that the temperature setpoint was maintained continuously at $23{ }^{\circ} \mathrm{C}$ for 48 hours.

To understand the relationship between the $\mathrm{DH}$ price and setpoint variations, the results shown in Table 1 and Figure 4 are compared. The Finnish synthetic DH price has smaller average prices and standard deviations in April and October which leads to no charging hours. On the contrary, February has the maximum hourly price and largest standard deviation which results in the longest charging period.

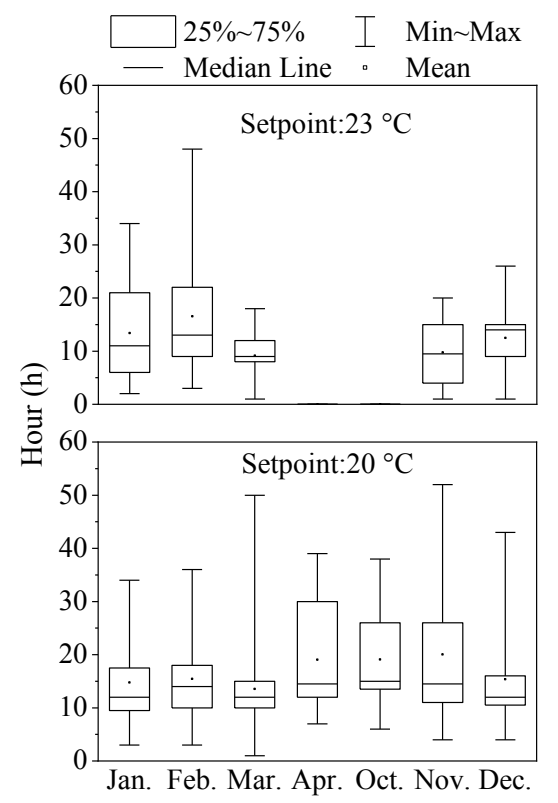

Figure 4. Setpoint variation hours for each month with marginal value $15 € / \mathrm{MWh}$.

To compare different marginal value effects, Table 5 shows the number of total setpoint variation hours for each month during the heating season. In the condition DR-15, there are 201 charging hours in total when the indoor temperature was set to $23{ }^{\circ} \mathrm{C}$ in January. Contrary to the marginal value $15 € / \mathrm{MWh}$, the case with marginal 
value $75 € / \mathrm{MWh}$ (FAB-DR-75) has only five charging hours which can be considered almost no charging actions during the heating season. The reason is that the higher marginal value decreases the possibility that the control signal is set to +1 . Moreover, the case with marginal value $75 € / \mathrm{MWh}$ have a higher number of discharging hours each month.

Table 5. Number of total setpoint variation hours for each month during the heating season.

\begin{tabular}{ccccc}
\hline \multirow{2}{*}{ Month } & \multicolumn{2}{c}{ DR-15 } & \multicolumn{2}{c}{ DR-75 } \\
\cline { 2 - 5 } & $23{ }^{\circ} \mathrm{C}$ & $20{ }^{\circ} \mathrm{C}$ & $23{ }^{\circ} \mathrm{C}$ & $20{ }^{\circ} \mathrm{C}$ \\
\hline Jan. & 201 & 354 & 0 & 455 \\
\hline Feb. & 215 & 247 & 0 & 358 \\
\hline Mar. & 119 & 366 & 0 & 413 \\
\hline Apr. & 0 & 419 & 0 & 419 \\
\hline Oct. & 0 & 458 & 0 & 458 \\
\hline Nov. & 78 & 401 & 0 & 442 \\
\hline Dec. & 175 & 369 & 5 & 415 \\
\hline $\begin{array}{c}\text { Total } \\
\text { hours }\end{array}$ & 788 & 2614 & 5 & 2960 \\
\hline
\end{tabular}

\subsection{Impacts on charging and discharging energies}

This section analyzes the charging and discharging energies of the DR cases. The purpose of this summarization is to illustrate the way in which these simulated buildings behave with the rule-based DR control from the perspective of $\mathrm{DH}$ producers.

The indoor air temperature changed by the setpoint signals analyzed in Section 5.1, and the heating power demand changed accordingly. Charging and discharging energies were calculated based on Eqs. (2) and (3). Figure 5 and 6 show the variation, median, and mean values of charging and discharging energies of each charging or discharging period per month during the heating season. Heating charging and discharging losses were considered in the simulation. However, they are not separately analysed in this study.

With marginal value $15 € / \mathrm{MWh}$, the maximum charging energy during a single charging period reaches $968 \mathrm{kWh}$ in February, which is close to the heat storage capacity of a fully mixed $28 \mathrm{~m}^{3}$ water tank with $\Delta \mathrm{T}$ of $30 \mathrm{~K}$. The Finnish synthetic DH price and the Helsinki outdoor temperature combined affect the charging and discharging energies. February is the coldest month with the longest charging period for 48 hours with the condition DR-15, which results in the highest maximum charging energy during the heating season. January, November, and December are colder months with higher price standard deviations, which results in relatively higher maximum charging and discharging energies compared to the rest months of the heating season. However, the mean charging and discharging energies are all close to $200 \mathrm{kWh}$ except in April and October. It indicates that the maximum charging and discharging energies change with the changes of Finnish synthetic DH price standard deviation per month.

With marginal value $75 € / \mathrm{MWh}$, the maximum and mean charging energies are small because of the reduction of charging hours.

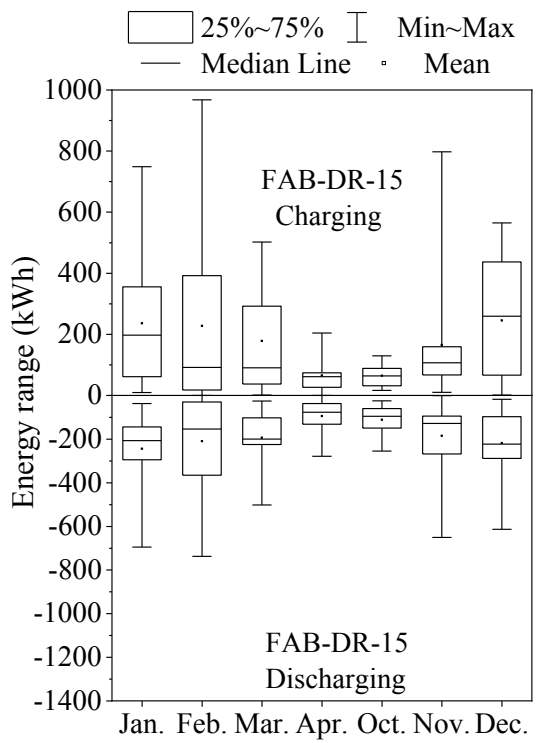

Figure 5. Variations of charging/discharging energies during a single charging/discharging period with marginal value 15 $€ / \mathrm{MWh}$.

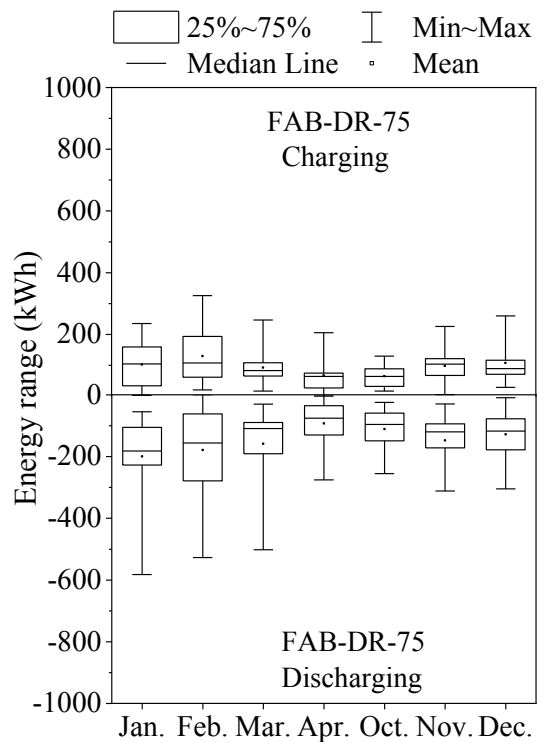

Figure 6. Variations of charging/discharging energies during a single charging/discharging period with marginal value 75 €/MWh.

Table 6 shows the total specific charging and discharging energies per month and whole heating season. Months with a more fluctuated $\mathrm{DH}$ price and a colder outdoor temperature have a higher amount of total specific charging and discharging energies. In case FAB-DR-15, the total specific charging and discharging energies are almost balanced per month and the total specific discharging energy is $0.3 \mathrm{kWh} / \mathrm{m}^{2}$ more than the charging energy of the whole heating season.

In case FAB-DR-75, the total specific charging energy of the whole heating season reduces nearly by half compared with case FAB-DR-15. Moreover, the 
amount of total specific discharging energy of the heating season reduces by $30 \%$. Charging energy decreased because of the reduction of charging hours, which resulted in less energy storage. Thus, less energy was released when the indoor air temperature dropped down, which caused less discharging energy.

Table 6. Total specific charging and discharging energies of the Finnish cases per heated net floor area.

\begin{tabular}{ccccc}
\hline \multirow{2}{*}{ Month } & \multicolumn{2}{c}{$\begin{array}{c}\text { Total specific } \\
\text { charging energy } \\
\left(\mathrm{kWh} / \mathrm{m}^{2}\right)\end{array}$} & \multicolumn{2}{c}{$\begin{array}{c}\text { Total specific } \\
\text { discharging energy } \\
\left(\mathrm{kWh} / \mathrm{m}^{2}\right)\end{array}$} \\
\cline { 2 - 5 } & $\begin{array}{c}\text { FAB- } \\
\text { DR-15 }\end{array}$ & $\begin{array}{c}\text { FAB- } \\
\text { DR-75 }\end{array}$ & $\begin{array}{c}\text { FAB- } \\
\text { DR-15 }\end{array}$ & $\begin{array}{c}\text { FAB- } \\
\text { DR-75 }\end{array}$ \\
\hline Jan. & 1.2 & 0.4 & -1.1 & -0.7 \\
\hline Feb. & 1.1 & 0.4 & -0.9 & -0.6 \\
\hline Mar. & 0.9 & 0.5 & -1 & -0.7 \\
\hline Apr. & 0.3 & 0.3 & -0.5 & -0.5 \\
\hline Oct. & 0.3 & 0.3 & -0.5 & -0.5 \\
\hline Nov. & 0.7 & 0.4 & -0.8 & -0.6 \\
\hline Dec. & 1.2 & 0.5 & -1 & -0.6 \\
\hline $\begin{array}{c}\text { Heating } \\
\text { season }\end{array}$ & 5.6 & 2.9 & -5.9 & -4.2 \\
\hline
\end{tabular}

\subsection{Impacts on energy flexibility}

Table 7 lists the seasonal energy flexibility factors calculated based on Eqs. (4) and (5). The range of them is from 4 to $8 \%$ for charging and from -6 to $-8 \%$ for discharging. The case with marginal value $15 € / \mathrm{MWh}$ (FAB-DR-15) is more flexible than the case FAB-DR75 with higher $F F^{+}$value and lower $F F^{-}$value.

Table 7. Flexibility factors.

\begin{tabular}{ccc}
\hline Case & $F F^{+}(\%)$ & $F F^{-}(\%)$ \\
\hline FAB- DR-15 & 7.7 & -8.1 \\
\hline FAB- DR-75 & 4.0 & -5.8 \\
\hline
\end{tabular}

\section{Conclusions}

This study investigates the effect of the rule-based DR control algorithm on energy flexibility of a district heated Finnish apartment building. Two different marginal values 15 and $75 € / \mathrm{MWh}$ were adopted in the control algorithm with the Finnish synthetic DH price.

For the hourly DH prices, the lower marginal value is more sensitive and active for price changes which leads to more charging actions while the higher marginal value weakened the price fluctuation effects.

The studied demand response control can significantly increase the flexibility of the energy use. The range of seasonal energy flexibility factors is from 4 to $8 \%$ for charging and from -6 to $-8 \%$ for discharging. The maximum and mean charging energies of a single charging period are mainly affected by the hourly $\mathrm{DH}$ price and the outdoor temperature. A more fluctuated hourly DH price and a lower outdoor temperature result in higher maximum and mean charging energies of charging periods. The indoor air temperature was also maintained in an acceptable range with DR control.

This study is part of the Smart Proheat - Smart Prosumer Heating Technologies and FINEST Twins projects. Smart Proheat project is funded by Business Finland and private companies Caverion Ltd., Fourdeg Ltd., Halton Ltd., and Aalto University as well as the Federal Ministry for Economic Affairs and Energy of Germany in the project; EnEff:Wärme SmartProHeaT: Smart Prosumer Heating Technologies, Subproject: Integration of smart prosumers into smart thermal grids (Project number: 03ET1598). FINEST Twins project is funded by European Union (Horizon 2020 programme, Grant No. 856602) and the Estonian government. Authors would like to thank the steering group of Smart Proheat project: M. Sc. Olli Nummelin and M. Sc. Nelli Melolinna from Caverion Ltd., M. Sc. Markku Makkonen from Fourdeg Ltd. and Dr. Panu Mustakallio from Halton Ltd. and the colleagues from University of Applied Sciences Hamburg: M.Sc. Jan Trosdorff, M. Sc. Moritz Verbeck and Prof. Dr. Hans Schäfers for support and fruitful discussions.

\section{References}

[1] European Commission, "2030 climate and energy framework." Climate Action - European Commission Available: https://ec.europa.eu/clima/policies/strategies/20 30 en. (accessed Jan. 6, 2021).

[2] European Commission, "2050 long-term strategy." Climate Action - European Commission. Available: https://ec.europa.eu/clima/policies/strategies/20 50 en (accessed Jan. 6, 2021).

[3] Finnish Government. Programme of Prime Minister Sanna Marin's Government (2019, Dec. 10). Inclusive and competent Finland - a socially, economically and ecologically sustainable society. Available at: http://urn.fi/URN:ISBN:978-952-287-811-3. IEA, "Energy Policies of IEA Countries: Finland 2018 Review - Analysis.” IEA. Available: https://www.iea.org/reports/energypolicies-of-iea-countries-finland-2018-review (accessed Jan. 6, 2021).

[5] F. C. Robert, G. S. Sisodia, and S. Gopalan, "A critical review on the utilization of storage and demand response for the implementation of renewable energy microgrids," Sustainable Cities and Society, vol. 40, pp. 735-745, 2018.

[6] S. Salo, A. Hast, J. Jokisalo, R. Kosonen, S. Syri, J. Hirvonen, and K. Martin, "The Impact of Optimal Demand Response Control and Thermal Energy Storage on a District Heating System," Energies, vol. 12, no. 9, p. 1678, 2019.

[7] R. Zafar, A. Mahmood, S. Razzaq, W. Ali, U. Naeem, and K. Shehzad, "Prosumer based energy management and sharing in smart grid," Renewable and Sustainable Energy Reviews, vol. 82, pp. 1675-1684, 2018. 
[8] L. Gelazanskas and K. A. Gamage, "Demand side management in smart grid: A review and proposals for future direction," Sustainable Cities and Society, vol. 11, pp. 22-30, 2014.

[9] G. Reynders, R. A. Lopes, A. MarszalPomianowska, D. Aelenei, J. Martins, and D. Saelens, "Energy flexible buildings: An evaluation of definitions and quantification methodologies applied to thermal storage," Energy and Buildings, vol. 166, pp. 372-390, 2018.

[10] R. G. Junker, A. G. Azar, R. A. Lopes, K. B. Lindberg, G. Reynders, R. Relan, and H. Madsen, "Characterizing the energy flexibility of buildings and districts," Applied Energy, vol. 225, pp. 175-182, 2018.

[11] R. D. Coninck and L. Helsen, "Quantification of flexibility in buildings by cost curves Methodology and application," Applied Energy, vol. 162, pp. 653-665, 2016.

[12] G. Reynders, J. Diriken, and D. Saelens, "Generic characterization method for energy flexibility: Applied to structural thermal storage in residential buildings," Applied Energy, vol. 198, pp. 192-202, 2017.

[13] J. L. Dréau and P. Heiselberg, "Energy flexibility of residential buildings using short term heat storage in the thermal mass," Energy, vol. 111, pp. 991-1002, 2016.

[14] H. Johra, P. Heiselberg, and J. L. Dréau, "Influence of envelope, structural thermal mass and indoor content on the building heating energy flexibility," Energy and Buildings, vol. 183, pp. 325-339, 2019.

[15] S. Janne, J. Jokisalo, R. Kosonen, K. Ville, J. Yuchen, and J. Philipp. "Demand Response Control of Space Heating in Three Different Building Types in Finland and Germany." Energies, vol. 13, no. 23, p. 6296, 2020.

[16] B. Vand, K. Martin, J. Jokisalo, R. Kosonen, and A. Hast, "Demand response potential of district heating and ventilation in an educational office building," Science and Technology for the Built Environment, vol. 26, no. 3, pp. 304-319, 2020.

[17] B. Alimohammadisagvand, J. Jokisalo, and K. Sirén, "Comparison of four rule-based demand response control algorithms in an electrically and heat pump-heated residential building," Applied Energy, vol.209, pp. 167179, 2018.

[18] Sisäilmastoluokitus 2018 (Classification of indoor environment 2018), Sisäilmayhdistys ry (Finnish Society of Indoor Air Quality), 2018). [online]. Available: https://www.rakennustietokauppa.fi/sivu/tuote/ rt-07-11299-sisailmastoluokitus-2018sisaympariston-tavoitearvot-suunnitteluohjeetja-tuotevaatimukset/2742604 (In Finnish).

[19] Indoor environmental input parameters for design and assessment of energy performance of buildings addressing indoor air quality, thermal environment, lighting and acoustics. SFS- EN 15251. Helsinki: Finnish standards association SFS, 2007.

[20] T. Kalamees, K. Jylhä, H. Tietäväinen, J. Jokisalo, S. Ilomets, R. Hyvönen, and S. Saku, "Development of weighting factors for climate variables for selecting the energy reference year according to the EN ISO 15927-4 standard," Energy and Buildings, vol. 47, pp. 53-60, 2012.

[21] Finnish Meteorological institute, "Energialaskennan testivuodet nykyilmastossa (Test years for energy calculation in current climate)." Ilmatieteen laitos. Available: http://ilmatieteenlaitos. fi/energialaskennantestivuodet-nyky (accessed 11 Sept. 2020).

[22] K. Martin, "Demand Response of Heating and Ventilation with in Educational Office Buildings," Master's Thesis. Aalto Univ. School of Eng., Dept. of Energy Tech. HVAC, Espoo, Finland, 2017. Available: https://aaltodoc.aalto.fi/handle/123456789/291 $\underline{49}$ 